\title{
METHOD OF VIRTUAL SPATIAL MANIPULATION IN TEACHING OF MATEMATICS
}

\section{Katarína ŽILKOVÁ}

\begin{abstract}
Teaching of mathematics in the context of information and communication technologies requires not only the innovation of traditional teaching methods, but also spurred the creation of new teaching practices. The contribution clarifies the principle of virtual spatial manipulation, as an important teaching method aimed at promoting development of spatial imagination. An overview of mathematics and geometry software suitable for solving of spatial problems gives their short characteristics together with suggestions for use. Usefulness of the use of virtual methods of spatial manipulation is illustrated by solving a simple spatial problem in the Cabri $3 D$ environment.
\end{abstract}

Key words: dynamics, geometry, interactivity, manipulation, spatial situation, geometry, virtual manipulation.

\section{METÓDA VIRTUÁLNEJ PRIESTOROVEJ MANIPULÁCIE VO VYUČOVANÍ MATEMATIKY}

\begin{abstract}
Abstrakt: Vyučovanie matematiky vprostredi informačných a komunikačných technológii si vyžaduje nielen inováciu tradičných vyučovacích metód, ale podnietilo aj vznik nových didaktických postupov. Príspevok objasňuje princíp virtuálnej priestorovej manipulácie, ako dôležitej didaktickej metódy zameranej na podporu rozvoja priestorovej predstavivosti. V prehlade vhodných matematicko-geometrických programových produktov určených na riešenie stereometrických úloh je uvedená ich krátka charakteristika spolu snámetmi na využitie. Užitočnost' využitia metódy priestorovej virtuálnej manipulácie je ilustrovaná na riešení jednoduchej stereometrickej úlohy v prostredi Cabri $3 D$.
\end{abstract}

Kl'účové slová: dynamika, geometria, interaktivita, manipulácia, priestorová situácia, stereometria, virtuálna manipulácia.

\section{Úvod}

O užitočnosti manipulačných aktivít vo vyučovaní matematiky pojednávajú vo svojich prácach viacerí autori. Najmä v oblasti rozvíjania predstáv o priestorových telesách sú ciel'avedomé manipulácie strojrozmernými objektmi dôležitou súčast’ou optimalizácie didaktických postupov. Napriek skutočnosti, že o dôležitosti rozvoja geometrických poznatkov nikto nepochybuje, z výsledkov rôznych prieskumov vyplýva, že v uvedenej oblasti výučby sú značné rezervy a nedostatky. K základným ciel'om vyučovania školskej stereometrie podla viacerých autorov patrí schopnost':

- zachytit' priestorovú situáciu v rovinnom obrázku,

- vidiet' rovinný obrázok priestorovo,

- vediet' zobrazit' základné typy telies, ich rovinné rezy a siete.
Dôležitou súčast'ou stereometrického vzdelania je naučit' žiakov manipulovat' s priestorovými objektmi v myšlienkach a predstavách. Podobne, ako ked' sa diet'a učí základným manipuláciám s rôznymi detskými stavebnicami a prechádza pri tejto činnosti rôznymi stupňami poznania, je potrebné postupne budovat' a rozvíjat' aj základné poznatky o stereometrii $\mathrm{v}$ siršom zmysle slova. $\mathrm{Na}$ ceste od manipulácie stelesami až po korektnú abstraktnú predstavu o nich je potrebné postupne zarad'ovat' rôznorodé úlohy a cvičenia, aby skúseností s priestorovými javmi bolo čo najviac.

Jedna z didaktických metód, ktorá nadväzuje na manipuláciu s modelmi telies a účinne podporuje rozvoj priestorovej predstavivosti je „virtuálna manipulácia“ s trojrozmernými objektmi $\quad \mathrm{v}$ prostredí počítačových programových produktov. 


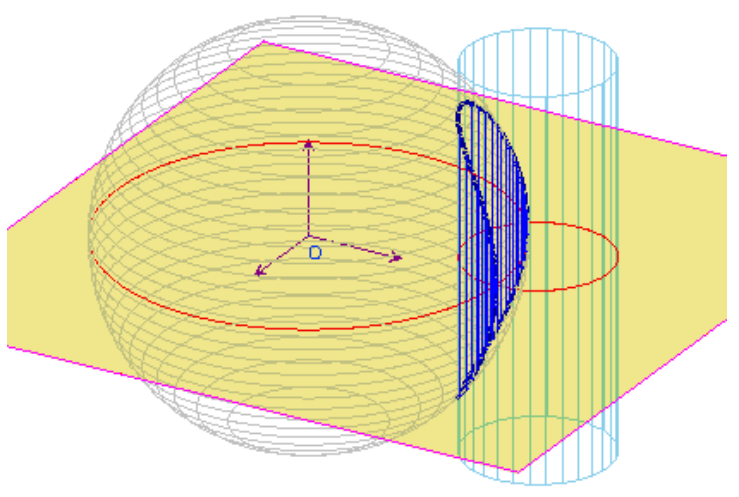

Obr. 1: Reprezentácia gule, valca a ich spoločného prieniku v Cabri II Plus.

Poznávanie niektorých vlastností priestorových telies napr. na monitore počítača, prípadne na interaktívnej tabuli, je užitočné najmä z pohl'adu častých problémov vyplývajúcich $\mathrm{z}$ nedostatočnej geometrickej gramotnosti žiaka v oblasti zobrazenia trojrozmerných objektov do rovinného obrazu. Schopnost' vidiet' zobrazované telesá trojrozmerne je $\mathrm{v}$ špeciálnych elektronických výučbových prostrediach podporená vd'aka vizualizačným možnostiam výpočtovej a zobrazovacej techniky.
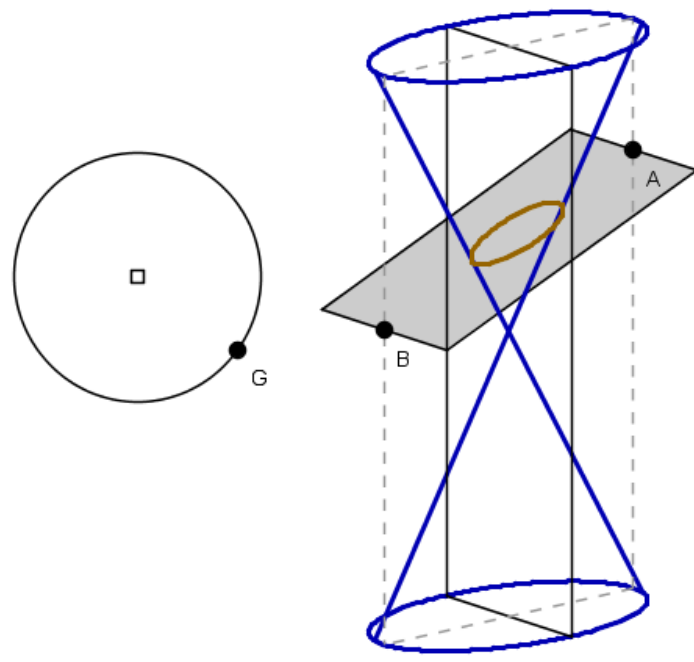

Obr. 2: 3D konštrukcia rezu na rotačnej kužel'ovej ploche v systéme C.a.R. http://mathsrv.kueichstaett.de/MGF/homes/grot hman/java/zirkel/doc_en/Demos/index.html.
V súčasnosti možno pri vyučovaní stereometrie využit', okrem už spomínaných prostredí dynamickej geometrie Cabri II Plus (obr. 1) a Compass and Ruler (obr. 2), aj rôzne špecializované programy určené na výučbu niektorých častí stereometrického učiva. Z hl'adiska načrtnutej problematiky sa javí ako výnimočne vhodný všeobecnejší dynamický softvér určený na riešenie úloh priestorovej geometrie s názvom Cabri 3D, prípadne užšie špecializovaný programový produkt $\mathrm{s}$ názvom Poly Pro (obr. 3). Pre konkrétnejšiu predstavu o potenciáli spomínaných programov a o ich didaktickom využití sa pokúsime obidva produkty $\mathrm{v}$ krátkosti charakterizovat', najmä v kontexte ich využitia vo vyučovaní matematických tém o geometrických telesách.

\section{Poly Pro - virtuálne skúmanie mnohostenov a ich vlastností}

Softvér s názvom Poly Pro (obr. 3, obr. 4) je príkladom špecializovaného, pomerne vydareného, programového produktu určeného na skúmanie vlastností špeciálnych typov mnohostenov. Je dostupný na www.peda.com a patrí do kategórie tzv. shareware, čo umožňuje bezplatné vyskúšanie, časovo a najmä rozsahovo obmedzené používanie. Softvér umožňuje užívatel'ovi sledovat' rôzne pohl'ady na zvolené špeciálne telesá v názornom zobrazení. V ponuke programu sú zobrazenia týchto typov telies: Platónove telesá, Archimedove telesá, hranoly a antihranoly, Johnsonove telesá, deltaédry, Katalánske telesá, dipyramídy a geodetické gul'ovité kupoly. O možnostiach programu a jeho didaktickom využití vo vyučovaní matematiky podrobne informuje O. Židek (2007), ktorý hodnotí program $\mathrm{z}$ viacerých hl'adísk. V stručnosti preberáme: „Telesá sa môžu skúmat' z hl'adiska konvexity, a taktiež z hl'adiska počtu vrcholov, stien a hrán. Z hl'adiska obsahovej didaktiky je program zaujímavý z pohl'adu klasifikácie a triedenia telies. Napokon treba zdôraznit', že vnímanie pohl'adov na telesá prostredníctvom monitoru je, na rozdiel od vnímania konkrétnych modelov telies, d'alším stupňom rozvoja abstrakcie“ (O. Židek, str. 208, 2007). $\mathrm{K}$ výhodám prípravy úloh a zadaní v prostredí programu Poly Pro autor príspevku zarad'uje nasledujúce vlastnosti:

- „animácia zobrazení telies umožňuje flexibilitu $\mathrm{v}$ individuálnom zadaní d’alších úloh pre jednotlivých žiakov (napr. pri 
zobrazovaní duálnych telies $\mathrm{k}$ daným telesám);

- finálne grafické produkty sú spravidla vel'mi estetické, čo riešitel'a vedomostne uspokojuje a povzbudzuje;

- riešenie vyžaduje minimálnu znalost’ teórie z vol'ného rovnobežného premietania (využívajú sa invarianty: incidencia, rovnobežnost' a podielový pomer);

- dá sa pohodlne zoznámit' so śpeciálnymi skupinami telies, ktoré sa v tradičnej školskej matematike nevyskytovali pre náročnost' ich zobrazení.“
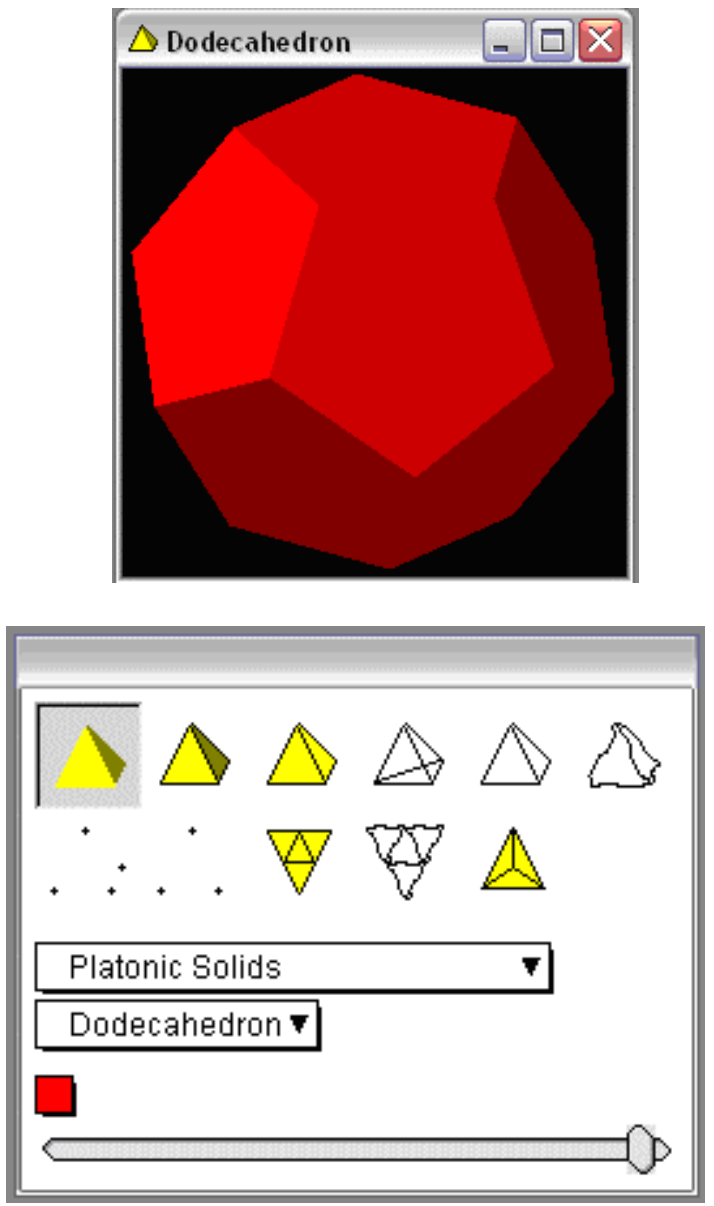

Obr. 3: Poly Pro, verzia 1.11, dostupné na www.peda.com.

Bližšia zmienka o programe a jeho ponuke nie je potrebná, pretože je zrozumitel'ný, l’ahko ovládatel'ný, a aj l'ahko dostupný. Cenné sú však informácie o skúsenostiach z využívania a námetoch aktivít, ktoré sa dajú využit' ako geometrické cvičenia:

1. „Rozhodni o viditel'nosti hrán jednotlivých telies (to program niekedy neurobí). Zvolenú viditel'nost' je možné zvýraznit' vyfarbením stien.

2. Z predtlače vrcholov telesa zostroj zobrazenie jeho hrán (stien) vrátane zvolenej viditel'nosti.

3. V predtlači zobrazenia „viditel'ných“ hrán telesa narysuj (čiarkovane) „neviditel'né“ hrany (steny).

4. V predtlači neúplného znázornenia vrcholov (hrán) narysuj d’alšie, s využitím poznatkov o rovnobežnom premietaní.

5. Rysuj do predtlače znázorneného telesa d'alšie objekty“ (O. Židek, str. 208, 2007).
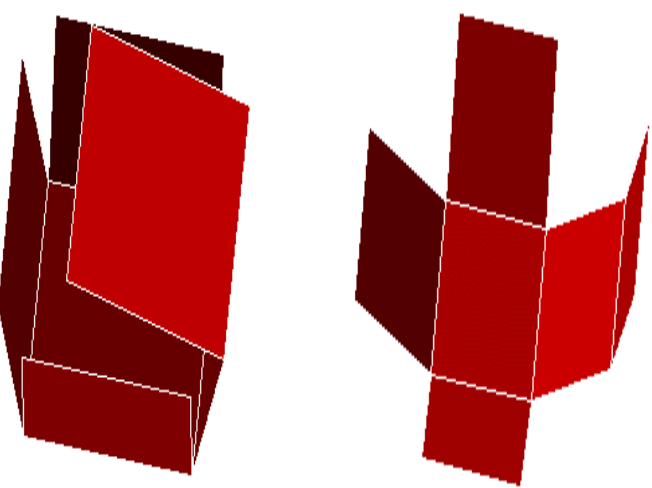

Obr. 4: Vizualizácia tvorby siete kocky v programe Poly Pro, sledovanie prechodu z roviny do priestoru a naopak, priprava metodického materiálu.

Z d'alších didaktických benefitov vyberáme:

- Objavným spôsobom možno prezentovat' princíp duality medzi telesami (kocka - osemsten, dvanást'sten - dvadsat'sten, atd'.). K riešeniu postačí schopnost' nájst' stred steny telesa a tento považovat' za vrchol nového telesa. Zatial' čo cvičenie na kocke je z konštrukčného hl'adiska jednoduché, cvičenie na d'alších telesách by bolo bez ponúkanej technológie vel'mi náročné.

- Pri skúmaní polopravidelných mnohostenov (Archimedovské telesá) možno využit' princíp „obsekávania“ vrcholov na pravidelných mnohostenoch (Platónových telesách). 
- Pomerne l'ahko sa dajú kombinovaným spôsobom zobrazit' niektoré hviezdicovité telesá (stella octangula) i d'alšie.

Z technického hl’adiska je zaujímavá skutočnost', že je možné exportovat' otáčajúce sa mnohosteny $\mathrm{v}$ tvare animovaných súborov typu *.gif.

\section{Cabri 3D - platforma na riešenie stereometrických úloh}

Všeobecnejším programom určeným na riešenie stereometrických úloh v Euklidovskom priestore $\mathrm{E}^{3}$ je Cabri $3 \mathrm{D}$ vyvíjaná tímom Cabrilog. Podobne, ako program Cabri II Plus, možno charakterizovat' aj jeho priestorový variant ako interaktívny geometrický dynamický systém, ktorý ponúka nástroje na riešenie geometrických úloh v priestore. $\mathrm{O}$ jeho základných vlastnostiach sa čitatel' môže dozvediet' $\mathrm{z}$ domovskej internetovej stránky (www.cabri.com), d'alej z vedeckých a recenzných prác J. Vaníčka (2005) a didaktické skúsenosti na Slovensku postupne zverejňuje D. Vallo $(2005,2007)$.

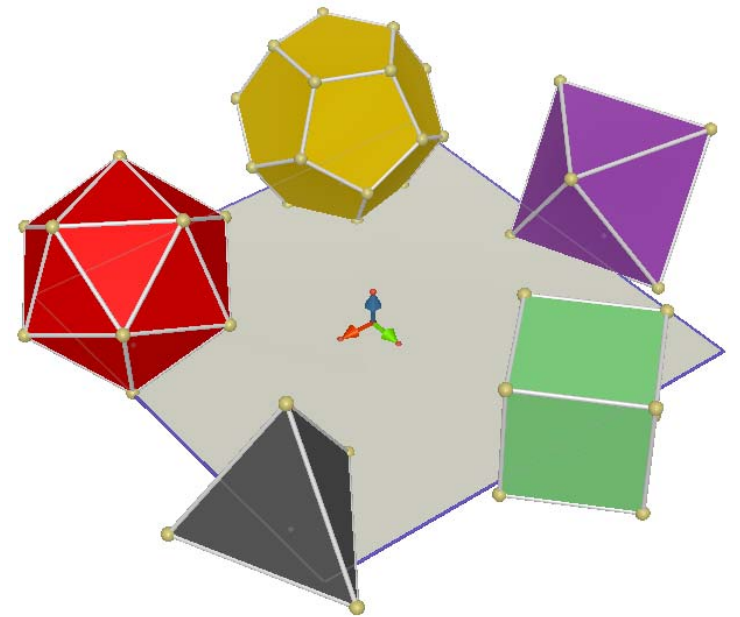

Obr. 5: Platónske telesá v Cabri 3D.

Avšak aj bez hlbšieho štúdia spomínaných prác možno konštatovat', že už prvé tri prívlastky uvedeného softvéru: interaktívny, geometrický a dynamický program konkretizujú a vypovedajú o jeho atribútoch. Prostredie programu Cabri 3D je intuitívne a ponuka konštrukčných nástrojov nie je vel'ká. Napriek tomu funkcionalita programu je dostatočná pre potreby školskej geometrie nielen $z$ obsahovej stránky, ale najmä z hl'adiska inovačných didaktických prístupov. Ak by sme chceli podrobit' ponuku

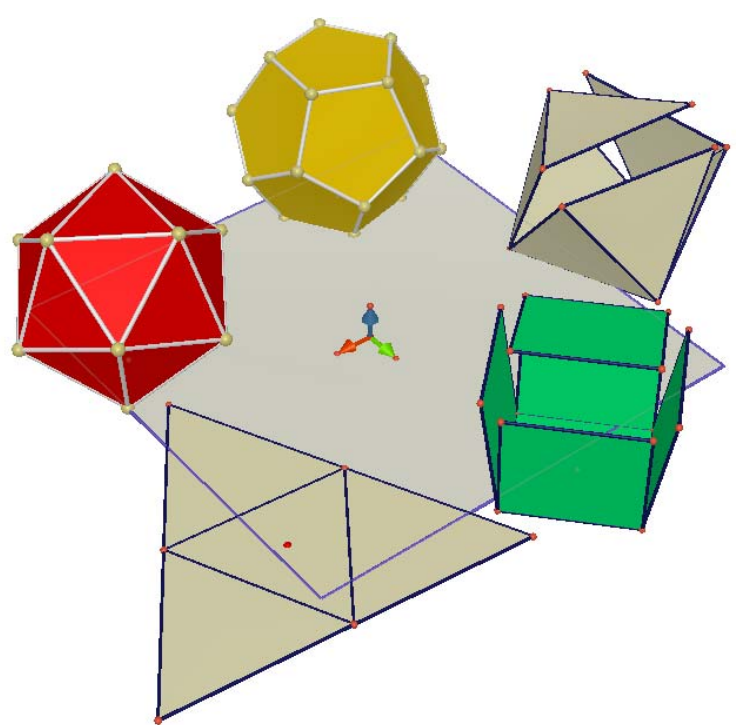

Obr. 6: Postupné „otváranie“ "telies až do siete $\checkmark$ Cabri 3D.

a vlastnosti Cabri 3D náročným klasifikačným kritériám, ktoré majú charakterizovat' celé stereometrické učivo z obsahovej stránky, treba konštatovat', že v programe nájdeme nástroje na:

- Rozvoj priestorovej predstavivosti.

- jednoduché konštrukcie zobrazení telies (štvorsten, kváder, hranol, ihlan, konvexný mnohosten, vrátane platónskych telies obr. 5)

- tvorba sietí uvedených telies (obr. 6)

- tvorba interaktívnych rezov telies

- možnost' zobrazenia dynamickej manipulácie stelesami (skúmanie z rôznych zorných uhlov, odval'ovanie a rozbal'ovanie telies, otáčanie),

- Využivanie kalkulatívnej stereometrie.

- možnost' merania vzdialeností, dížok, obvodov, obsahov, objemov a povrchov, vel'kostí uhlov, zavedenie súradnicového systému, využívanie rovníc pri riešení stereometrických úloh,

- Prehíbenie vedomostí z teoretickej stereometrie.

- nástroje na využívanie priestorových transformácií (stredová súmernost', osová súmernost', rovinová súmernost', posunutie, otočenie, rovnol'ahlost', inverzia).

So zostrojenými priestorovými útvarmi v Cabri 3D možno manipulovat', prispôsobovat' ich vzhl'ad, animovat' ich a zanechávat' stopu zvolených pohybujúcich sa objektov. $\mathrm{K}$ tradičným nástrojom dynamických geometrií patrí možnost' prehrávania konštrukcie krok po 
kroku. K najdôležitejším prednostiam môžeme zaradit' jednoduchý webový export, čím sa otvárajú možnosti prípravy on-line výučbových materiálov a dynamických obrázkov využitel'ných v rôznych elektronických didaktických dokumentoch.

V priamej výučbe systém môže slúžit' ako:

- nástroj virtuálneho rysovania (virtuálny výkres, virtuálne pravítko a kružidlo),

- nástroj na prezeranie hotových konštrukcií, ich skúmanie, experimentovanie s nimi vrátane d'alších manipulácií,

- demonštračný nástroj (doplnok výkladu, zobrazovacia pomôcka napr. pre diskusiu),

- nástroj na rozvijanie priestorovej predstavivosti a jej overovanie.

Jednu z alternatív didaktického využitia softvéru Cabri 3D uvedieme pri riešení nasledujúcej úlohy.

\section{Úloha o nepriehl'adnej kocke}

Miško si $z$ dovolenky priniesol špeciálnu kocku zlepenú z ôsmich kociek - štyri sú biele priehl'adné a štyri čierne nepriehl'adné. Kocky sú uložené tak, aby sa cez kocku nedalo vidiet' ani zhora dole, ani spredu dozadu, ani zl'ava doprava (obr. 7). Fero si chce urobit' tiež takú nepriehl'adnú kocku, ale väčšiu - z 27 kociek. V obchode zistil, že za jednu čiernu nepriehl'adnú kocku zaplatí až 20 korún, zatial' čo za bielu priehl'adnú len 8 korún. Najmenej kol'ko korún ho bude stát' vel'ká kocka, ak za lepidlo zaplatí 40 korún?

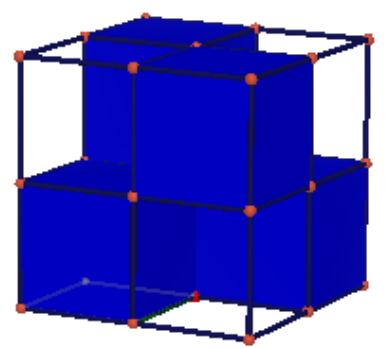

Obr. 7: Ilustračný obrázek.

\section{Autorské riešenie:}

„Ked’že Fero chce za vel'kú kocku zaplatit' čo najmenej korún, musí kúpit' čo najmenej nepriehl'adných čiernych kociek, lebo sú drahšie ako priehl'adné biele. Najprv zistíme, najmenej kol'ko čiernych kociek musí kúpit' a ako ich musí umiestnit', aby celá vel'ká kocka bola nepriehl'adná. Vel'ká kocka má byt' z 27 kociek, preto bude mat' rozmery $3 \times 3 \times 3$. Aby nebolo vidiet' spredu dozadu, musia byt' na každom poschodí najmenej 3 kocky (v každom „predozadnom“ rade po jednej). Tieto by mali byt' umiestnené tak, aby súčasne zabraňovali pohl'adu zhora dole (teda aby v každom $\mathrm{z}$ deviatich stĺpcov bola jedna kocka) a súčasne aby zabraňovali pohl'adu zl'ava doprava. Fero musí kúpit' 9 čiernych nepriehl'adných kociek, za ktoré zaplatí $9.20=180$ korún. Zvyšných 27$9=18$ kociek bude bielych priehl'adných a zaplatí za ne 18.8=144 korún. Spolu s lepidlom za 40 korún zaplatí Fero $180+144+40=364$ korún. Vel'ká kocka ho bude stát najmenej 364 korún."

\section{Komentár:}

Otázka v uvedenej úlohe je formulovaná tak, že predznamenáva jednoduchý numerický výpočet, ktorý však netvorí jadro problému. Úloha sa charakterovo redukuje na stereometrickú, a len jej úspešné riešenie môže byt' základom zdarného ukončenia riešenia úlohy. Hladá sa odpoved' na otázku: Zistite najmenej kol'ko čiernych - nepriehl'adných kociek potrebujeme a ako ich rozmiestnime, aby celá vel'ká kocka bola nepriehl'adná.

V zadaní úlohy je diet’at'u predložený ilustračný obrázok kocky, ktorú si priniesol $z$ dovolenky Miško. Úloha je teda určená pre žiakov, u ktorých sa predpokladá schopnost' korektnej interpretácie ilustračného obrázka, prípadne textovej formulácie úlohy. Pre riešitel'a by nemal byt' problém vel'kú kocku $\mathrm{s}$ rozmermi $2 \times 2 \times 2$ poskladat' $\mathrm{z}$ poskytnutých kociek dvoch farieb. Je zrejmé, že poskladat' kocku tak, aby sme overili jej priehl'adnost', či nepriehl'adnost' z pohl'adov zhora dole, spredu dozadu a aj zl'ava doprava je problematické vzhl'adom na výber materiálu priehl'adných kociek. Ak by sme priehl'adné kocky ignorovali a skúsili použit len čierne, stavba nie je kompaktná, a teda sa nedá poskladat'. Takže už aj vo fáze interpretácie úlohy musí byt' žiak schopný istej abstrakcie, či je to $\mathrm{v}$ práci s konkrétnym dvojfarebným modelom, alebo v myšlienkovej manipulácii s kockou s rozmermi $2 \times 2 \times 2$. Po zväčšení kocky na $3 \times 3 \times 3$ sa význam použitia konkrétnych kociek $\mathrm{v}$ dvoch farebných prevedeniach prinajmenšom znižuje, pretože predstava jednotlivých horizontálnych a vertikálnych vrstiev vel'kej kocky z hl'adiska ich priehl'adnosti je náročná, nie však vylúčená. Pre žiakov, u ktorých abstrakčná úroveň ešte nedosiahla manipuláciu v myšlienkach, môže byt' využitie vhodného softvéru prospešným nástrojom na 
spredmetnenie. Platforma Cabri 3D sa ponúka nielen $\mathrm{v}$ demonštračnej rovine (učitel' pripraví modely v prostredí Cabri 3D a predvedie dynamické zmeny $\mathrm{v}$ závislosti od zmeny zorného uhl'a pohl'adu), ale najmä v možnosti individuálneho skladania kocky samotným riešitel’om postupným pridávaním menších kociek.

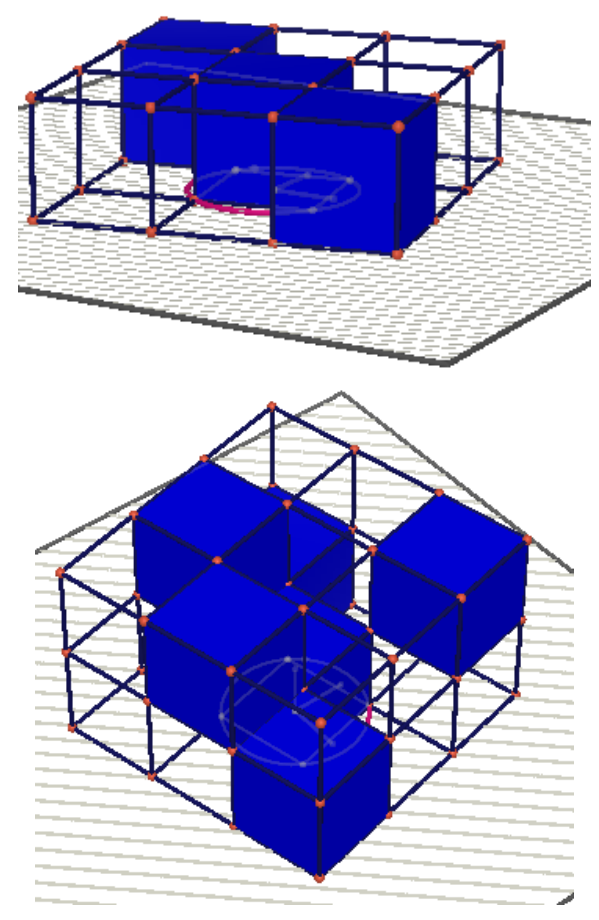

Obr. 8: Skladanie vel'kej kocky postupne po horizontálnych vrstvách s nastavovaním priehl'adnosti.

Ked’že dynamická geometria ponúka aj možnost' nastavenia istých vizuálnych vlastností, je možné definovat' kocky ako nepriehl'adné. Žiak si môže zvolit' rôzne stratégie skladania virtuálnych kociek, a z didaktického hl'adiska je užitočné všímat' si zvolené postupy. Ak pominieme náhodnost' $\mathrm{v}$ skladaní a nesystémovost', v zásade sú možné tri riešitel'ské stratégie. Prvý strategický postup spočíva v postupnom dopĺn̆aní pôvodnej Miškovej kocky typu 2x2x2 o d’alšie kocky až po rozmer $3 \times 3 \times 3$, pričom každej pridanej kocke treba nastavit' atribút farebnosti, či priehl'adnosti. Druhá stratégia je založená na postavení kocky $3 \times 3 \times 3$ po jednotlivých poschodiach (prípadne vertikálnych rezoch) od úplne prvej kocky až po poslednú, taktiež s nastavením priehl'adnej, alebo farebnej vlastnosti každej kocky (obr. 8, obr. 9. obr. 10). Tretia stratégia ja založená na metóde farbenia kocky, t. j. žiak môže mat' pripravenú bezfarebnú stavbu $3 \times 3 \times 3$ (alebo si ju sám zostrojí) a nastavovaním atribútu priehl'adnosti pre každú malú kocku postupne stavbu „farbí“.

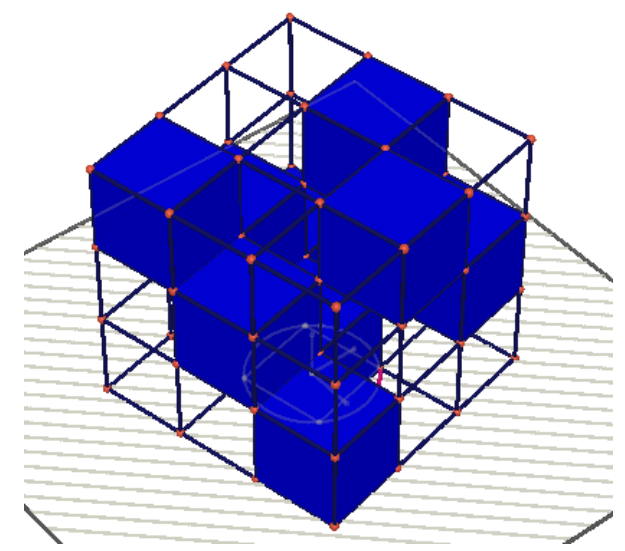

Obr. 9: Ukončená konštrukcia kocky.

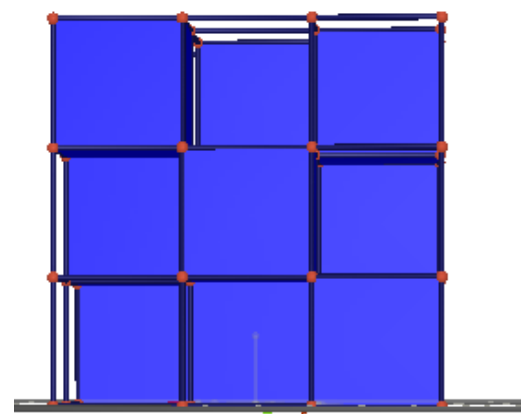

Obr. 10: Jeden z pohl'adov na kockuverifikácia priehl'adnosti.

Vd'aka možnosti „zmeny stanovišt’a pozorovatel'a" v Cabri 3D je prikladanie kociek jednoduché a názorné. Zmenit' pohl'ad na nákresňu možno pridržaním pravého tlačidla myši a jej pohybom do požadovaného smeru. Táto prednost' umožňuje žiakovi po zostavení vel'kej kocky overit' jej nepriehl'adnost' a korigovat' prípadné omyly vo svojich hypotézach. Taktiež sa jednoduchou zmenou pohladu zistí celkový počet použitých nepriehl'adných kociek, pričom konštrukciu netreba rušit'. Ak je riešitel' $\mathrm{v}$ predstavách vyspelejší vie nepriehl'adných kociek. Na pomoc menej vyspelému riešitel'ovi môže poslúžit' nástroj ,prehrávanie konštrukcie“.

\section{Záver}

Pri riešení stereometrických úloh vo všeobecnosti závisí výber metódy riešenia otáčaním kocky zistit' počet použitých úlohy od úrovne abstrakčného stupňa poznania jednotlivca. Kým na najnižšom stupni v abstraktno-gradačnej štruktúre treba počítat' 
s tým, že pre diet’a je nutné teleso si ohmatat', pohrat' sa s ním, u vyspelého riešitel'a (po abstrakčnom zdvihu) očakávame, že predstava o skladbe jednotlivých kociek bude prebiehat' čisto myšlienkovou manipuláciou. Medzi uvedenými stupňami zrelosti riešitel'a stereometrických úloh je niekol'ko úrovní, ktorých prekonanie je podmienkou úspešnosti. Domnievame sa, že metóda virtuálnej priestorovej manipulácie $\mathrm{v}$ špeciálnych programových prostrediach v kombinácii s ostatnými tradičnými a osvedčenými metódami môže poskytnút' dostatok skúseností a poznatkov potrebných na zvládnutie jednotlivých abstrakčných úrovní.

\section{Literatúra}

(1) GROTHMANN, R.: Compass and Ruler. [cit. 12. dec. 2008]. URL: http://mathsrv.kueichstaett.de/MGF/homes/grothmann/java/zirke 1/doc en/index.html.

(2) ŽIDEK, O.: 2007. Manipulačné a virtuálne štúdium niektorých vlastností špeciálnych mnohostenov. In: Vyučování matematice z pohledu kompetencí žáka a učitele 1. stupně základního vzdělávání. Plzeň: Západočeská univerzita, s. 204-209, 2007, ISBN 978-807043-548-9.

(3) VANÍČEK, J.: CABRI 3D - cesta do další dimenze? In: Konferencia „Užití počitačú ve výuce." České Budějovice: $2005 . \quad$ URL: http://www.pf.jcu.cz/cabri/cabri3d/dalsi_dimen ze.pdf.

(4) VALLO, D: Riešenie stereometrických úloh v programe Cabri 3D. In: Konferencia „Matematika včera, dnes a zajtra". Ružomberok: Pedagogická fakulta KU, str. 280-283, 2006. ISBN 80-8084-066-0.

(5) VALLO, D: Možnosti Cabri 3D vo vyučovaní geometrie. In: 39. konferencia slovenských matematikov, Jasná pod Chopkom. Žilina: Edis - vydavatel'stvo Žilinskej univerzity, 47 s. ISBN 978-80-8070-772-9. URL: http://www.konferenciajasna.sk/article/9/ . (6) ŽILKOVÁ, K.: WebMatika - školská matematika $v$ prostredí IKT. Úloha o nepriehl'adnej kocke. [cit. 12. dec. 2008]. URL: http://www.webmatika.sk/Cabri3D/ nepriehladna.kocka.html .

(7) PEDAGOGUERY SOFTWARE INC.: Poly Pro. [cit. 12. dec. 2008]. URL: http://www.peda.com/polypro/.

(8) EXAM testing: sút’až MAKS6, šk. rok 2007-2008, 3. kolo, úloha 4. [cit. 12. oct. 2008]. URL: http://www.maks.sk .

PaedDr. Katarína Žilková, PhD.

Katedra matematiky a informatiky PdF

Univerzita Komenského v Bratislave

Račianska 59

81334 Bratislava

Web: www.km.fedu.uniba.sk

E-mail: katarina@zilka.sk 